\title{
PEST POTENCIAL OF Sitophilus zeamais ON BRAZIL NUT UNDER STORAGE CONDITIONS
}

\author{
POTENCIAL DE Sitophilus zeamais COMO PRAGA DA CASTANHA-DO-BRASIL EM \\ CONDIÇÕES DE ARMAZENAMENTO
}

\author{
Evaldo Martins PIRES ${ }^{1}$, Roberta Martins NOGUEIRA ${ }^{\mathbf{1}}$; Rodrigo Sinaidi ZANDONADI ${ }^{\mathbf{~}}$ \\ Robert Lee KOCH${ }^{2}$; Marcus Alvarenga SOARES ${ }^{3}$; Cliver Fernandes FARDER-GOMES ${ }^{4}$ \\ 1. Universidade Federal de Mato Grosso, Sinop, MG, Brazil. evaldo@ufmt.br; 2. University of Minnesota, Saint Paul, MN, USA. \\ koch0125@umn.edu; 3. Universidade Federal dos Vales do Jequitinhonha e Mucuri, Diamantina, MG, Brazil.; 4. Universidade Federal \\ de Viçosa, Viçosa, MG, Brazil.
}

\begin{abstract}
The Brazil nut, fruit of Bertholletia excelsa H.B.K., a native plant of the Amazon region and may be considered one of the main extractivist products of countries like Bolivia, Colombia, Guyana, Venezuela, Peru and Brazil. In Brazil this plant can be found in the states of Acre, Amapá, Amazonas, Mato Grosso, Pará, Rondônia, Roraima and Tocantins. Species of the Coleoptera and Lepidoptera, have been classified as pest potentials of Brazil nut under storage conditions. Sitophilus zeamais (Coleoptera: Curculionidae) is one of the main insect pests attacking grain stores worldwide. This specie may be observed attacking grains in the field and in storage facilities (cross-infestation), presenting a wide variety of hosts. The purpose of this study was to assess the potential of adults of this species feed on Brazil nuts, and also to identify the type of injury as well as the life span of this coleopteran exposed to the meat of the Brazil nut. No feeding injury was observed on the surface of Brazil nuts and the life span of the insects was similar in treatments both with and without this food source in all populations evaluated. Due to the fact that $S$. zeamais adults do not injure, or feed on the Brazil nut, this beetle is not able to colonize this product and therefore may be considered a non-pest insect for stored Bertholletia excelsa almonds stored.
\end{abstract}

KEYWORDS: Absence of injury. Life span. Non-pest insect.

\section{INTRODUCTION}

The seeds of Bertholletia excelsa H.B.K. (Lecythidaceae), popularly known as Brazil nut, is one of the main extractivist products of the Amazon Biome (IBGE, 2017). In Brazil alone, this production chain provides dwellings and income for approximately 15,000 families, thus motivating preservation of this valuable tree species (SANTOS, 2012). Recent research has contributed to the improvement of techniques and post-harvest procedures, implementing specific parameters for the classification of this product, which can favor the production of a higher-quality Brazil nut (ÁLVARES et al., 2012; CARNEIRO et al., 2018, 2017; MARTINS et al., 2012; MONTEIRO; NOGUEIRA; PIRES, 2016).

Brazil nut is a seasonal product, collected generally between November and April, depending on the region (BRASIL, 2012). Although it is a exclusively Amazon forest product, Brazil nut is consumed worldwide (SCHIRIGATTI et al., 2016). Storage facilities has been developed to stabilize the supply rates for Brazil nut, however majority of those facilities are not used exclusively for Brazil nut storage, but also for raw or processed food based on rice, soybean, corn among others.

Multi-product storage facility is a suitable environment for an eventual pest migration between products, which worries industrialists, vendors and researchers. Therefore, Brazil nut might become a new food source for the known grain pests causing great losses

Important insects, classified as storage pests in Brazil nut, have been investigated regarding the potential to consolidate as important pests for Brazil nut, such as: Hypothenemus hampei (Ferrari, 1867) (Coleoptera: Scolytidae) - "coffee borer" (GUMIER-COSTA, 2009), Plodia interpunctella (Lepidoptera: Pyralidae) (GOMES; KRUG; TAVARES, 2015), Curculionidae larvae (CASTRILLÓN; PURCHIO, 1988), Tribolium castaneum (Coleoptera: Tenebrionidae) (PIRES et al., 2017), Rhyzopertha dominica (Coleoptera: Bostrichidae) (PIRES; NOGUEIRA, 2018) and the moths Ephestia kuehniella (Lepidoptera: Pyralidae) and Sitotroga cerealella (Lepidoptera: Gelechiidae) (PIRES; NOGUEIRA; LACERDA, 2018). The types of injuries that have been observed on the surface of Brazil nuts that are caused by Coleoptera and Lepidoptera are described as holes, galleries, 
scratches and particles of loose material (flour) (PIRES; NOGUEIRA; LACERDA, 2018, 2017; PIRES; NOGUEIRA, 2018).

\section{Sitophilus zeamais (Coleoptera:}

Curculionidae) is one of the most important pests of stored products around the world (CARVALHO et al., 2012; FRAGOSO; GUEDES; PETERNELLI, 2005). This specie may be observed attacking grains in the field and in storage facilities (crossinfestation), presenting a wide variety of hosts such as wheat, corn, rice, barley and triticale, and its high biotic potential leads to significant population growth over a short period of time (GALLO et al., 2002; LORINI et al., 2015). Considering the lack of studies about $S$. zeamais behavior regarding Brazil nut, the objective of this study was to: verify if $S$. zeamais adults feed on Brazil nuts, to characterize the injuries caused as well as the life span of this beetle exposed to this Amazonian product as a food source.

\section{CONTENTS}

The ability of $S$. zeamais adults to cause feeding injury to and survive on Brazil nut was evaluated under controlled conditions of $28 \pm 2{ }^{\circ} \mathrm{C}$ and $60 \pm 10 \% \mathrm{RH}$ using Biochemical Oxygen Demand (BOD) chamber. After removing the protective shell, the Brazil nut was cut vertically into three parts using a surgical scalpel (Figure 1), with the middle portion being offered to the insects in one of two treatments. This procedure was accomplished to verifying if these insects would feed in the portions where the skin cover the endocarp or preferred the internal part of the nut. In treatment 1 (T1), 10 adult specimens were kept together with the Brazil nut and in treatment 2 (T2), another 10 insects were kept without food source. In both treatments, distilled water was offered using a moistened cotton ball that was changed daily.

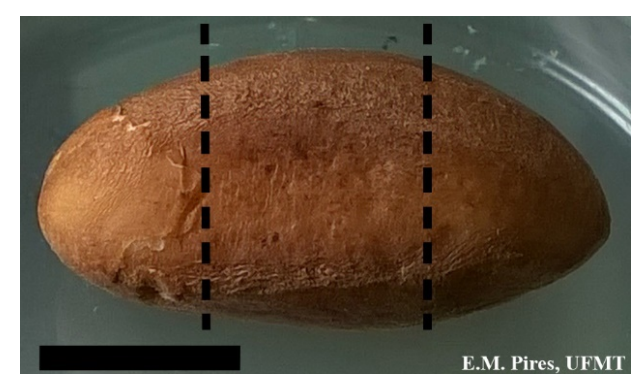

Figure 1. Detail of where cuts were made in the Brazil nut with a surgical scalpel. $\mathrm{Bar}=1 \mathrm{~cm}$.

The tests were carried out using "PraFesta" brand round plastic pots with a $145 \mathrm{~mL}$ capacity with 10 adult specimens placed per pot, totaling 25 replicates for each treatment. Separate experiments were conducted using adults $S$. zeamais obtained from the following populations: (A) from a mass rearing from "Laboratório de Pragas e Vetores da Amazônia / Cerrado (LPVAC)" at Federal University of Mato Grosso (UFMT-Sinop); (B) from corn stored at the "Laboratório de Nutrição Animal e Forragicultura (LNAF)" at UFMT-Sinop; (C) from corn stored in facility 1 located in Sinop; (D) from corn stored in facility 2 located in Sinop; and (E) from a mass rearing from the "Insetário" at Federal University of Vales of Jequitinhonha and Mucuri (UFVJM), situated in Diamantina city, Minas Gerais, Brazil.

A stereoscopic microscope was used to search for injuries caused in the nuts surface. The life span of this coleopteran in treatments was determined by counting the number of dead insects in a daily basis, until all individuals were dead. The life span means were calculated using the following equation $\delta=\sum_{i=1}^{\mathrm{n}} \mathrm{Xi}$. fí, where: $\mathrm{x}=$ mean of days lived;

$\mathrm{Xi}=$ each day of the evaluation;

$\mathrm{ff}=$ number of live insects on each day of evaluation.

The data were submitted to the normality test of Lilliefors and followed by a F test. Statistical analysis were accomplished in Bioestat 5.0 software was used (AYRES et al., 2007) with $0.05 \%$ significance assuming error type I.

None of the evaluated populations caused feeding injuries on the surfaces of the Brazil nuts. During daily observations, all specimens remained distant from the Brazil nuts. The inadequacy of this food was further indicated by the observed life span of $S$. zeamais kept in the presence of Brazil nuts or without food, receiving only distilled water. The life span of the specimens obtained from all populations was similar with and without Brazil nut offered as a food source: from LPVAC $(F=0.06, p=0.79)$; from LNAF $(\mathrm{F}=0.01, \mathrm{p}=0.91)$; from company $1(\mathrm{~F}=$ $0.004, \mathrm{p}=0.94)$; from company $2(\mathrm{~F}=0.08, \mathrm{p}=$ $0.76)$, and from UFVJM $(\mathrm{F}=0.006, \mathrm{p}=0.93)$ (Figure 2). 


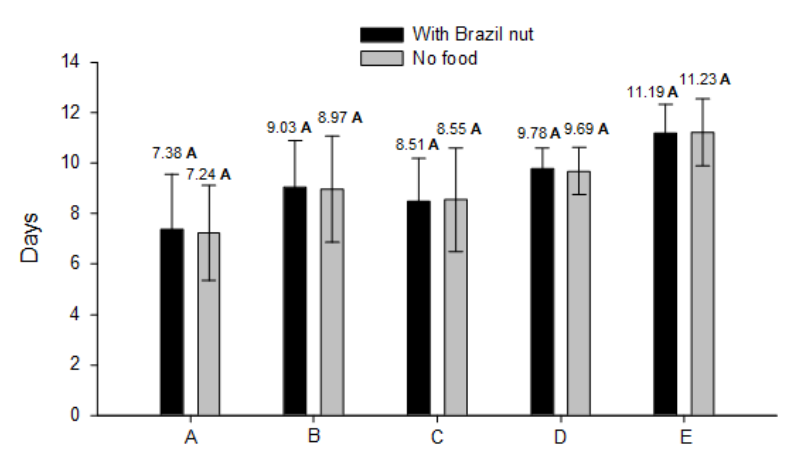

Figure 2. Life span (mean $\pm \mathrm{SD}$ ) for Sitophilus zeamais (Coleoptera: Curculionidae) adults exposed to feeding treatments with Brazil nuts or without food. Insects obtained from: (A) mass rearing from LPVAC at UFMT; (B) corn stored from LNAF at UFMT; (C) corn stored in facility 1 in Sinop; (D) corn stored in facility 2 in Sinop; and (E) mass rearing from "Insetário" at UFVJM.

Sitophilus zeamais appears to present no pest threats to Brazil nut under storage condition. This was evidenced through this study by 1) the absence of feeding injury on the nuts, 2) the insects not being observed in contact with the Brazil nut, and 3) the life span of the insects exposed to Brazil nut being similar to those who had no food source. Furthermore, the mean life spans of the $S$. zeamais populations exposed to Brazil nut ranged from about 7 to 11 days, which is considerably less than the reported life spans of $122.3 ; 120.3 ; 117.6$ and 126 days for this insect when exposed to suitable food sources such as corn, rice, sorghum and millet, respectively, at similar environmental conditions 24 $-30{ }^{\circ} \mathrm{C} ; 60 \pm 10 \%$ RU (OJO; OMOLOYE, 2016).
The reason this insect did not feed on the Brazil nut is not understood. However, plants are able to prevent pest attacks by producing secondary metabolic compounds and proteins that have a toxic, repellent and/or anti-nutritional effect for insects (RANI; JYOTHSNA, 2010; WAR et al., 2012).

Considering the results obtained in this research, the behavior of $S$. zeamais adults exposed to Brazil nut needs to be further studied.

\section{ACKNOWLEDGEMENTS}

We thank Mr. Célio J. Silva, Farlem A. Oliveira, Felix E. Agostini and Atila De L. Molinari for the technical support during this research.

RESUMO: A castanha-do-brasil, fruto da Bertholletia excelsa H.B.K., que é uma planta nativa da região Amazônica e esse fruto pode ser considerado um dos principais produtos extrativistas de países como Bolívia, Colômbia, Guiana, Venezuela, Peru e Brasil. No Brasil, essa planta pode ser encontrada nos estados do Acre, Amapá, Amazonas, Mato Grosso, Pará, Rondônia, Roraima e Tocantins. Espécies de Coleoptera e Lepidoptera foram classificadas como potenciais pragas da castanha-do-brasil em condições de armazenamento. Sitophilus zeamais (Coleoptera: Curculionidae) é uma das principais pragas de insetos que atacam os armazéns de grãos em todo o mundo. Esta espécie pode ser observada atacando grãos no campo e em unidades armazenadoras (infestação cruzada), apresentando uma grande variedade de hospedeiros. O objetivo deste estudo foi avaliar o potencial de adultos dessa espécie em se alimentarem de castanha-do-brasil, e também, identificar o tipo de lesão e o tempo de vida deste coleóptero exposto castanha-do-brasil. Não foi observada lesão na superfície da castanha-do-brasil e o tempo de vida dos insetos foram semelhantes nos tratamentos com e sem alimento em todas as populações avaliadas. Devido ao fato de que adultos de S. zeamais não lesionaram ou se alimentaram da castanha-do-brasil, este besouro não é capaz de colonizar este produto e, portanto, pode ser considerado um inseto não-praga para as amêndoas de Bertholletia excelsa armazenadas.

PALAVRAS-CHAVE: Ausência de lesão. Tempo de vida. Inseto não-praga. 


\section{REFERENCES}

ÁlvareS, V. S.; CASTRO, I. M.; COSTA, D. A.; LIMA, A. C.; MADRUGA, A. L. S. Qualidade da castanha-do-brasil do comércio de Rio Branco, Acre. Acta Amazônica, Manaus, v. 42, n, 2, p. 269-274, 2012. http://dx.doi.org/10.1590/S0044-59672012000200013

AYRES, M.; AYRES JUNIOR, M.; AYRES, D. L.; SANTOS, A. BIOESTAT: Aplicações estatísticas nas áreas das ciências biomédicas. 2007.

BRASIL. Ministério da Agricultura, Pecuária e Abastecimento. PROBIO II: Série boas práticas de manejo para o extrativismo sustentável orgânico castanha-do-brasil (Bertholletia excelsa H.B.K.). 2012. 49 p.

CARNEIRO, J. S.; NOGUEIRA, R. M.; PIRES, E. M.; VALLADÃO, D. M. S. Restrictions to use oven in determining water content for Brazil nuts. Nativa, Sinop, v. 5, n. 1, p. 42-46, 2017.

https://doi.org/10.5935/2318-7670.v05n01a07

CARNEIRO, J. S.; NOGUEIRA, R. M.; MARTINS, M. A.; VALLADÃO, D. M. S.; PIRES, E. M. The ovendrying method for determination of water content in Brazil nut. Bioscience Journal, Uberlândia, v. 34, n. 3, p. 595-602, 2018. https://doi.org/10.14393/bj-v34n3a2018-37726

CARVALHO, M. O.; PIRES, I.; BARBOSA, A.; BARROS, G.; RIUDAVETS, J.; GARCIA, A. C.; BRITES, C.; NAVARRO, S. The use of modified atmospheres to control Sitophilus zeamais and Sitophilus oryzae on stored rice in Portugal. Journal of Stored Products Research, v. 50, p, 49-56. 2012.

https://doi.org/10.1016/j.jspr.2012.05.001

CASTRILLÓN, A. L.; PURCHIO, A. Fungos contaminantes e produtores d e aflatoxinas em castanha do pará (Bertholletia excelsa Humb. \& Bonpl. 1808). Acta Amazônica, Manaus, v. 18, n, 3, p. 173-183. 1988. http://dx.doi.org/10.1590/1809-43921988183183

FRAGOSO, D. B.; GUEDES, R. N. C.; PETERNELLI, L. A. Developmental rates and population growth of insecticide-resistant and susceptible populations of Sitophilus zeamais. Journal of Stored Products Research, v. 41, p. 271-281. 2005. https://doi.org/10.1016/j.jspr.2004.03.008

GALLO, D.; NAKANO, O.; CARVALHO, R. P. L.; BAPTISTA, G. C.; BERTI-FILHO, E.; PARRA, J. R. P.; ZUCCHI, R. A.; ALVES, S. B.; VENDRAMIM, J. D.; MARCHINI, L. C.; LOPES, J. R. S.; OMOTO, C. Manual de entomologia agrícola, 2. ed. Piracicaba: Fealq, 2002. 920 p.

GAROUSI, F. The essentiality of selenium for humans, animals, and plants, and the role of selenium in plant metabolism and physiology. Acta Universitatis Sapientiae, Cluj-Napoca, v. 10, n. 1, p. 75-90. 2017. https://doi.org/10.1515/ausal-2017-0005

GOMES, F. B.; KRUG, C.; TAVARES, J. G. First record of the indian meal moth, Plodia interpunctella (Hubner 1813) (Lepidoptera: Pyralidae) for Brazil nut. Bioscience Journal, Uberlândia, v. 31, n. 6, p. 17081710. 2015. https://doi: 10.14393/BJ-v31n6a2015-29433

GUMIER-COSTA, F. First record of the coffee berry borer, Hypothenemus hampei (Ferrari) (Coleoptera: Scolytidae), in Pará nut, Bertholletia excelsa (Lecythidaceae). Neotropical Entomology, v. 38, n. 3, p. 430431. 2009. http://dx.doi.org/10.1590/S1519-566X2009000300020

IBGE. Pevs 2016: Produção da silvicultura e da extração vegetal 2017. Available: https://agenciadenoticias.ibge.gov.br/agencia-noticias/2013-agencia-de-noticias/releases/16981-pevs-2016producao-da-silvicultura-e-da-extracao-vegetal-alcanca-r-18-5-bilhoes.html. 2017. (Accessed 12.13.18).

LORINI, I.; KRZYZANOWSKI, F. C.; FRANÇA-NETO, J. B.; HENNING, A. A.; HENNING, F. A. Manejo integrado de pragas de grãos e sementes armazenadas, 1. ed. Brasília: Embrapa, 2015. 84 p. 
MARTINS, M.; PACHECO, A. M.; LUCAS, A. C. S.; ANDRELLO, A. C.; APPOLONI, C. R.; XAVIER, J. J. M. Brazil nuts: determination of natural elements and aflatoxin. Acta Amazônica, Manaus, v. 42, n. 1, p. 157164. 2012. https://doi.org/10.1590/s0044-59672012000100018

MONTEIRO, L. M.; NOGUEIRA, R. M.; PIRES, E. M. A valid method for determining the water content of the Brazil nut (Bertholletia excelsa). Bioscience Journal, Uberlândia, v. 32, n. 4, p. 952-959. 2016. http://dx.doi.org/10.14393/BJ-v32n4a2016-33287

OJO, J. A.; OMOLOYE, A. A., 2016. Development and life history of Sitophilus zeamais (Coleoptera: Curculionidae) on cereal crops. Advances in Agriculture, p. 1-8. http://dx.doi.org/10.1155/2016/7836379

PIRES, E. M.; NOGUEIRA, R. M. Damage caused by Rhyzopertha dominica (Fabricius, 1792) (Coleoptera: Bostrichidae) in stored Brazil nuts. Scientific Electronic Archives, Sinop, v. 11, p. 57-61. 2018

PIRES, E. M.; NOGUEIRA, R. M.; LACERDA, M. C. Damage caused by Ephestia kuehniella (Lepidoptera: Pyralidae) and Sitotroga cerealella (Lepidoptera: Gelechiidae) to Brazil nuts. Florida Entomologist, Lutz, v. 101, n. 4, p. 684-687. 2018. https://doi.org/10.1653/024.101.0407

PIRES, E. M.; SOUZA, E. Q.; NOGUEIRA, R. M.; SOARES, M. A.; DIAS, T. K. R.; OLIVEIRA, M. A. Damage caused by Tribolium castaneum (Coleoptera: Tenebrionidae) in stored Brazil nut. Scientific Electronic Archives, Sinop, v. 10, p. 1-5. 2017.

RANI, P. U.; JYOTHSNA, Y. Biochemical and enzymatic changes in rice plants as a mechanism of defense. Acta Physiologiae Plantarum, v. 32, n. 4, p. 695-701. 2010. https://doi.org/10.1007/s11738-009-0449-2

SANTOS, J. C. Árvore do conhecimento castanha-do-brasil. Agência Embrapa de Informação

Tecnológica. Available in: https://www.agencia.cnptia.embrapa.br/gestor/castanha-dobrasil/arvore/cont000fthdobw602wyiv80otz6x94idbylx.html. 2012. (Accessed 12.13.18).

SCHIRIGATTI, E. L.; AGUIAR, G. P.; CARLOS, J.; LEODORO, G.; FREGA, J. R.; ALMEIDA, A. N.; HOEFLICH, V. A. Market behavior for in shell Brazil nuts produced in Brazil from 2000 to 2010. Floresta e Ambiente, Seropédica, v. 23, n. 3, p. 369-377. 2016. http://dx.doi.org/10.1590/2179-8087.075614

VICKERMAN, D. B.; YOUNG, J. K.; TRUMBLE, J. T. Effect of selenium-treated alfalfa on development, survival, feeding, and oviposition preferences of Spodoptera exigua (Lepidoptera: Noctuidae). Environmental Entomology. v. 31, n. 6, p. 953-959. 2002. https://doi.org/10.1603/0046-225x-31.6.953

WAR, A. R.; PAULRAJ, M. G.; WAR, M. Y.; IGNACIMUTHU, S. Herbivore-induced resistance in different groundnut germplasm lines to asian armyworm, Spodoptera litura (Fab.) (Lepidoptera: Noctuidae). Acta Physiologiae Plantarum, v. 34, n. 1, p. 343-352. 2012. https://doi.org/10.1007/s11738-011-0833-6 